\title{
Effect of 5-thio-D-glucose on protein synthesis in vitro by various types of cells from rat testes
}

\author{
M. Nakamura and P. F. Hall \\ Department of Physiology, California College of Medicine, University of California, \\ Irvine, California 92717, U.S.A.
}

It has been shown that 5-thio-D-glucose (thioglucose) inhibits protein biosynthesis by highly purified fractions of immature spermatids (Zysk, Bushway, Whistler \& Carlton, 1975; Nakamura \& Hall, 1976). The inhibition occurs when thioglucose is added to spermatids in vitro or administered in vivo for as short a time as 2 days (Nakamura \& Hall, 1976). Thioglucose is a chemical analogue of glucose, and spermatids are highly dependent upon glucose as a source of energy for protein syntheses (Paul, Paul, Kopo, Bender \& Everett, 1953; Waites \& Setchell, 1964). It is likely, therefore, that the contraceptive action of thioglucose may be associated with inhibition of protein synthesis in spermatids. In the study by Nakamura \& Hall (1976) the response to thioglucose was not confined to spermatids but was also observed (to a lesser degree) in other fractions of testicular cells. These fractions were, however, contaminated by spermatids and it could not be determined whether the inhibition of protein synthesis was confined to spermatids. The present studies were designed to approach this problem by examining the effect of thioglucose on cell fractions other than spermatids, using methods which produced fractions of greater purity.

\section{Methods and results}

The methods of preparing cell fractions from testes of adult rats using enzymatic digestion and centrifugal elutriation and for identifying and examining the cells for purity, viability and yields have all been described in detail previously (Nakamura \& Hall, 1976). Spermatocyte $\left(S_{\max } 11 \cdot 5-17 \cdot 5\right)$ and mature spermatid $\left(S_{\max }<4 \cdot 4\right)$ fractions were prepared by the same method (Grabske, Lake, Gledhill \& Meistrich, 1975; Nakamura \& Hall, 1976). This mature spermatid fraction was purified by a second centrifugal elutriation $\left(S_{\max } 1 \cdot 5-4 \cdot 0\right)$ before use. Leydig and Sertoli cell fractions were obtained as described by Hall, Irby \& de Kretser (1969) and Dorrington, Roller \& Fritz (1975), respectively. For preparations of immature spermatids and spermatocytes the rats were killed at 33 days of age and at 50 days for preparation of mature spermatids.

The methods used to measure incorporation of amino acids into proteins by the cells were as described by Means \& Hall (1967), Dorrington et al. (1975) and Nakamura \& Hall (1976). In all cases, incubation with $0.097 \mathrm{nmol} \mathrm{L}-\left[{ }^{3} \mathrm{H}\right]$ phenylalanine (sp. act. $40 \mathrm{Ci} / \mathrm{mmol}$ : NEN, Boston) in $3 \mathrm{ml}$ was performed at $34^{\circ} \mathrm{C}$ for $60 \mathrm{~min}$. The phenylalanine was purified before use (Block, Durrum \& Zweig, 1955).

The preparations of spermatids, Leydig cells and Sertoli cells all excluded Trypan blue ( $>90 \%$ ), consumed oxygen and produced lactate. The cells appeared intact by light microscopy and showed the yields, purities and morphological characteristics described in the published methods by which they were prepared. In each case, purity was greater than $90 \%$. Spermatocytes prepared by centrifugal elutriation were $88 \pm 3 \%$ pure (mean and range of 8 determinations) and viability was $>98 \%$. Immature spermatids and mature spermatids were $>90 \%$ pure with a viability $>96 \%$. Cell suspensions prepared by enzymatic digestion (Nakamura \& Hall, 1976) from rats aged 14 days showed the following distribution of cell types: spermatogonia, $26 \%$; Sertoli cells, $31 \%$; Leydig cells, $36 \%$; preleptotene spermatocytes, $12 \%$. During enzymatic digestion, the buffered medium was the same as that used in other studies except that $\mathrm{Ca}^{2+}$ and $\mathrm{Mg}^{2+}$ were omitted because these ions have been reported to impair cell separation in testes of young rats (Davis \& Schuetz, 1975). 
Table 1. Mean \pm S.E.M. incorporation of $\left[{ }^{3} \mathrm{H}\right]$ phenylalanine into protein $(\mathrm{d} / \mathrm{min} / \mathrm{mg}$ testicular protein) by various fractions from rat testes in vitro (no. of observations in parentheses)

\begin{tabular}{|c|c|c|c|c|c|c|}
\hline & $\begin{array}{l}\text { Immature } \\
\text { spermatids }\end{array}$ & $\begin{array}{c}\text { Mature } \\
\text { spermatids }\end{array}$ & $\begin{array}{l}\text { Spermato- } \\
\text { cytes }\end{array}$ & $\begin{array}{c}\text { Cell } \\
\text { suspension } \\
\text { (14-day-old } \\
\text { rats) }\end{array}$ & $\begin{array}{l}\text { Sertoli } \\
\text { cells }\end{array}$ & $\begin{array}{l}\text { Leydig } \\
\text { cells }\end{array}$ \\
\hline Saline & $\begin{array}{r}5075 \pm \\
230(8)\end{array}$ & $\begin{array}{r}6094 \pm \\
628(5)\end{array}$ & $\begin{array}{r}2378 \pm \\
120(8)\end{array}$ & $\begin{array}{r}3151 \pm \\
180(4)\end{array}$ & $\begin{array}{r}35,004 \pm \\
3783(5)\end{array}$ & $\begin{array}{r}454 \pm \\
37(6)\end{array}$ \\
\hline $\begin{array}{l}\text { Thioglucose } \\
(20 \mathrm{mM})\end{array}$ & $\begin{array}{l}4033 \pm \\
159(8)^{*}\end{array}$ & $\begin{array}{r}4212 \pm \\
315(5)\end{array}$ & $\begin{array}{l}1984 \pm \\
\quad 62(8)^{* *}\end{array}$ & $\begin{array}{r}3357 \pm \\
223(4)\end{array}$ & $\begin{array}{r}30,487 \pm \\
1,368(5)\end{array}$ & $\begin{array}{l}500 \pm \\
142(6)\end{array}$ \\
\hline $\begin{array}{l}\text { Glucose } \\
\quad(10 \mathrm{~mm})\end{array}$ & $\begin{array}{r}6380 \pm \\
294(8)\end{array}$ & $\begin{array}{r}11684 \pm \\
1024(5)\end{array}$ & $\begin{array}{r}3030 \pm \\
187(8)\end{array}$ & $\begin{array}{r}3120 \pm \\
390(4)\end{array}$ & $\begin{array}{r}32,251 \pm \\
1756(5)\end{array}$ & $\begin{array}{r}470 \pm \\
48(6)\end{array}$ \\
\hline $\begin{array}{l}\text { Glucose } \\
(10 \mathrm{~mm})+ \\
\text { thioglucose } \\
(20 \mathrm{mM})\end{array}$ & $\begin{array}{l}5059 \pm \\
247(8) \ddagger\end{array}$ & $\begin{array}{l}8805 \pm \\
639(5) \dagger\end{array}$ & $\begin{array}{r}3013 \pm \\
131(8)\end{array}$ & $\begin{array}{r}3612 \pm \\
357(4)\end{array}$ & $\begin{array}{r}32,821 \pm \\
1906(5)\end{array}$ & $\begin{array}{r}535 \pm \\
71(6)\end{array}$ \\
\hline
\end{tabular}

Significantly different (paired $t$ tests) from saline value: ${ }^{*} P<0.05,{ }^{* *} P<0.01$.

Significantly different (paired $t$ tests) from value with glucose alone: $\uparrow P<0.05 ; \ddagger P<0.01$.

As shown in Table 1, glucose stimulated incorporation of $\left[{ }^{3} \mathrm{H}\right]$ phenylalanine into protein by immature spermatids and incorporation was inhibited by thioglucose. These findings confirm our previous report (Nakamura \& Hall, 1976) and are shown here because the present studies were performed with 33-day-old rats (instead of 50-60 days) to facilitate comparison with values for other cells used in these studies.

Inhibition of incorporation by mature spermatids by thioglucose was seen only in the presence of glucose. In the spermatocyte fraction thioglucose inhibition did not occur in the presence of glucose; similar results were obtained when $50 \mathrm{~mm}$-thioglucose (+ glucose) and $10 \mathrm{~mm}$-thioglucose (- glucose) were used (data not shown). There were no significant changes of incorporation by the 14-day-old testicular suspensions, Sertoli cells or Leydig cells.

\section{Discussion}

In considering thioglucose as a potential male contraceptive, importance attaches to the question of which germinal cells are affected by the drug. It is clear from the studies of Zysk et al. (1975) that the histological changes produced by thioglucose depend upon dose and duration of treatment. About $95 \%$ of the drug is excreted within $6 \mathrm{~h}$ (Zysk et al., 1975) and thioglucose may be suitable for intermittent administration if a specific cell type is affected by the drug. Intermittent administration would greatly diminish the potential danger to other organs (e.g. the nervous system) which use glucose as a metabolic substrate.

It is clear from the present results that doses of thioglucose which cause significant inhibition of protein synthesis in spermatids are without effect upon Sertoli or Leydig cells when the drug is added to medium containing these cells (Table 1). This observation is consistent with the histological evidence of Zysk et al. (1975) that these two cell types remained normal after administration of thioglucose for 7 weeks, by which time all germinal cells were destroyed. The resistance of Leydig cells is of interest, because the drug is reported not to decrease libido (Zysk et al., 1975).

Spermatocytes show a small degree of inhibition when incubated with thioglucose and without glucose, whereas in the presence of glucose there is no inhibition. Since glucose is available to this cell type in vivo, it is likely that it would be protected from the effects of those concentrations of thioglucose that inhibit protein synthesis in immature spermatids. 
The question of whether protein synthesis by spermatogonia is affected by thioglucose will only be settled with the aid of pure preparations of these cells. At present, such preparations are not available on such a scale as to permit direct examination of the problem. However, the conspicuous difference between the cell populations of young (14 days) and mature rats lies in the absence of spermatids in the former. The fact that thioglucose does not inhibit protein synthesis in testes from 14-old-day rats is consistent with an effect of the inhibitor chiefly on spermatids, although it cannot be assumed that the responses of the Sertoli and Leydig cells of young rats are similar to those of adult rats.

If spermatids are the testicular cells most vulnerable to the effects of thioglucose and their differentiation could be interrupted for several days, it is likely that spermatogenesis would not proceed normally for the entire generation of spermatids so affected. If such an effect could be exerted once in every spermatogenic cycle, it is not unlikely that infertility would result. Such considerations warrant careful exploration of the effects of thioglucose administered in various doses in vivo upon protein synthesis by spermatids-a much more sensitive index than the histological changes so far studied (Zysk et al., 1975).

This work was supported by National Science Foundation Grant No. GB43493.

\section{References}

Block, R.J., Durrum, E.L. \& ZweIG, G. (1955) $A$ Manual of Paper Chromatography and Paper Electrophoresis, pp. 75-126. Academic Press, New York.

Davis, J.C. \& Schuetz, A.W. (1975) Separation of germinal cells from immature rat testis by sedimentation at unit gravity. Expl Cell Res. 91, 69-86.

Dorrington, J.H., Roller, N.F. \& Fritz, I.B. (1975) Effect of follicle-stimulating hormone on cultures of Sertoli cell preparations. Molec. cell. Endocr. 3, 57-70.

Grabske, R.J., Lake, S., Gledhill, B.R. \& Meistrich, M.L. (1975) Centrifugal elutriation: separation of spermatogenic cells on the basis of sedimentation velocity. J. cell. Physiol. 86, 177-190.

Hall, P.F., Irby, D.C. \& de Kretser, D.M. (1969) Conversion of cholesterol to androgens by rat testis; comparison of interstitial cells and seminiferous tubules. Endocrinology 84, 488-496.
Means, A.R. \& Hall, P.F. (1967) Effect of FSH on protein biosynthesis in testis of the immature rat. Endocrinology 81, 1151-1160.

Nakamura, M. \& Hall, P.F. (1976) Inhibition by 5thio-D-glucopyranose of protein biosynthesis in vitro in spermatids from rat testis. Biochim. Biophys. Acta 447, 474-483.

Paul, H.e., Paul, M.F., Kopo, F., Bender, R.C. \& Everetr, G. (1953) Carbohydrate metabolism studies on the testis of rats fed certain nitrofurans. Endocrinology 53, 585-592.

Waites, G.M.H. \& Setchell, B.P. (1964) Effect of local heating on blood flow and metabolism in the testis of the conscious ram. J. Reprod. Fert. 8, 339-349.

ZYSK, J.R., BUSHWAY, A.A., WhISTLER, R.L. \& CARLTON W.W. (1975) Temporary sterility produced in male mice by 5-thio-D-glucose. J. Reprod. Fert. 45, 69-72.

Received 23 September 1976 